\title{
医学教育，臨床研修，専門医研修と老年医学
}

\section{3. 新・内科専門医制度について}

New certification system for the specialist of internal medicine

\section{横山 彰仁}

\section{要 約}

新・専門医制度は，認定内科医制度が廃止されるなど内科領域に大きな影響を与えたが，2018 年に始ま り順調に経過している．新專門医は，総合的な内科研修を重視しながらも内科の多様性に配慮したプログラ ムに従って, 多施設において J-OSLER を用いて研修を行い, 病歴要約の形成的評価を経て試験に合格すれ ば, 内科学会および機構によって認定される. 新制度は医師のためではなく, 国民のための改革であること が重要な基本的視点である.

Key words 専攻医, プログラム制, 研修施設群, 日本専門医機構

（日老医誌 $2019 ； 56 ： 30-36$ )

\section{新制度の背景}

国民にとって分かりにくい多種多様な専門医が乱立 し, 専門医制度の在り方が議論されるようになり,2011 年秋に厚生労働省の「専門医の在り方検討委員会」が 発足し議論された。2013 年 4 月の最終答申では国民 目線に立ち,「中立的な第三者機関による専門医と養成 プログラム認定の統一化」基本的診療領域と subspecialty 領域からなる二段階制」総合診療医を基本領域 に追加」などの今後の日本の専門医制度の方向性を提 示した。そして第三者機関である日本専門医機構（以 下, 機構と略す) が 2014 年に設立され, 統一的な専 門医制度の整備が開始されることとなった。これによ り内科領域においても新制度が構築されることとなっ たわけであるが，これらの経緯については別稿を参照 されたい1).

新内科専門医制度は 2015 年以降の新たな医師に対
して適応され，新制度に扔ける研修は機構により認定 されたプログラムに基づいて行われる。 内科領域の特 徵としては，1）総合内科研修の重視，2）多施設での 研修，3）内科の多様性に配虑，4）web 版研修手帳 “J-Osler”の利用が挙げられる.

\section{新制度への移行に関して}

近年の医学の進歩に伴い, 内科領域の知識・技術 · 技能が高度化した結果，大学病院あるいは大病院にお ける内科の専門分化が進行し，内科全般を診療する医 師を必要とする地域あるいは患者のニーズとのミス マッチが生じた。これまでの内科認定医資格は 2 年間 の初期研修に 1 年の内科研修を最低期間としたもので あり，内科全般の研修を義務としていたものの，その 実態として不十分な場合も多かった，そこで，新内科 専門医は現行の内科認定医よりも高いレベルとし，新

高知大学血液・呼吸器内科学（日本内科学会認定医制度審議会会長）

連絡責任者：横山彰仁 高知大学血液・呼吸器内科学〔テ783-8505 高知県南国市岡豊町小蓮〕

e-mail: ayokoyama@kochi-u.ac.jp

doi: 10.3143 /geriatrics.56.30 


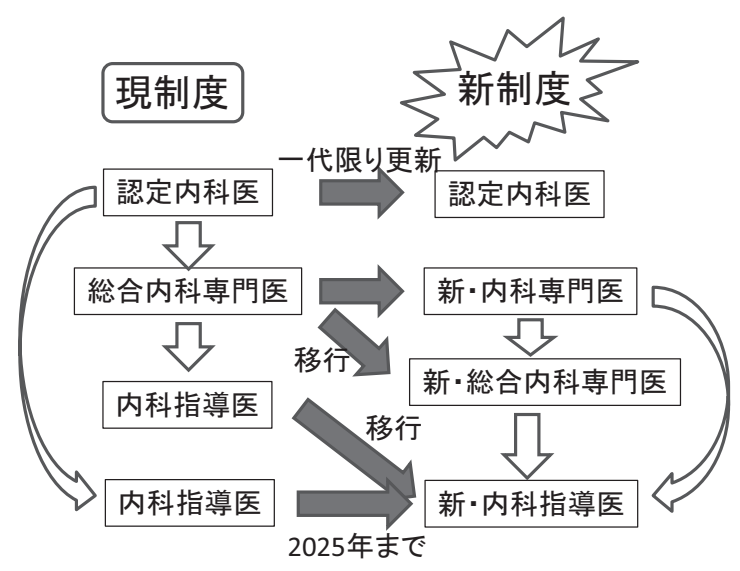

図 1 現行制度と新制度の相違と移行 認定内科医は新規の認定はないが，一代限り継続 して認定更新される。総合内科専門医資格はその ままサブスペシャルティの専門医としての新・総 合内科専門医として継続され, 希望者は新指導医 に移行する. 認定内科医で現行の依頼指導医の場 合も 2025 年までの期限付きではあるが，そのま ま新指導医に移行できる.

制度では初期 2 年+専攻医研修 3 年と定められたこと から, 内科全般における知識・技能・技術を習得させ る general な研修を必須とした。 ただし，研修の内容 こそが最も重要であることは変わりがない21.

認定内科医の新たな認定は行わないが，図 1 に示す ように，現在の認定内科医資格は，そのまま日本内科 学会の独自資格として, 一代に限り更新を行うことが 出来る。ただ, 制度の複雑さや事務的負担の軽減, ま た特に認定内科医を基礎としたサブ専門医の認定とい う点では, 認定医の更新を新専門医更新（現時点で更 新制度は策定されていない) に近づけることも必要と 考えられる。

現行の認定内科医試験や総合内科専門医試験は, 2020 年まで存続する. 現在(あるいは 2020 年までに), 総合内科専門医を保持し希望するものは新指導医に移 行できる。このため, 2014 年度から, (1)認定内科医 の更新 1 回以上, かつ(2)現在も内科に従事していると いう条件で，本受験に際して病歴要約の提出を免除す る経過措置を実施している。また，2025年までの暫 定措置として旧制度の指導医は, そのまま新指導医と なることが可能である. なお，機構における指導医は
専門医の更新者の「役割」としているが, 内科領域で は「資格」として認定される

総合内科専門医は新制度の内科専門医としても更新 される予定であり，更新基準も機構により統一された ものとなる（内科領域においては未定ながら 2021 年 から機構による更新がなされる予定である)。ただ, 総合内科専門医の存続を求める声が多く, 後述のよう に更なる generalityを目指した内科のサブスペシャ ルティ領域として残すことが決定されている.

\section{旧制度との違い $)^{3)}$}

新制度は基本的にはプログラム制であり，複数の施 設群（表 1）において，機構において審査・承認され たプログラムを実施することとなる。これらのうち， 特別連携施設は内科領域独自のもので，指導医がいな い施設であっても，基幹施設の指導医が密に指導可能 な場合は，プログラムに編入し地域医療を実践できる こととしている。これはまた同時に, 都道府県により 事情は異なるものの, 地域枠等の卒業生に配慮したも のでもある。ただし，本施設での研修期間は 1 年以内 としている.

専門研修の目標と達成度を明確化し, 専門知識, 専 門技能, 経験すべき疾患・病態, 学術活動に達成度を 設けており, 症例に関する専攻医の達成目標は, 主病 名で主担当医として 200 症例以上, 内科領域全 70 疾 患群を受け持つことである（修了要件はそれらの 80\%).70疾患群の内訳は『研修手帳 (疾患群項目表)』 に記載している，著しく偏った研修とならないよう， general な研修を担保するために, 主病名・主担当医 であることを要求している。そして J-Osler（図 2）に おいて, 随時に症例・技術・技能を登録・蓄積し, そ れを指導医が確認・評価していく，本システムは専攻 医の研修内容の評価にとどまらず，専攻医からの指導 医および研修プログラム評価も行われ，各研修プログ ラムの改善にも活かされる. 研修状況が可視化される ことから，プログラムの実施状況の実態も把握可能な システムとなっている。現時点 (2018.9.14) で, 29,000 例を超える症例が登録されている.

新制度において 3 年間の研修期間が設定されたこと 
表 1 研修施設群の要件

\begin{tabular}{|c|c|c|c|}
\hline 専門研修施設群 & 基幹施設 & 連携施設 & 特別連携施設 \\
\hline 臨床研修指定病院 & 必須 & 必須でない & 必須でない \\
\hline 研修プログラム管理委員会 (上部委員会) & 設置 & & \\
\hline 統括責任者 & 1 名（指導医） & & \\
\hline プログラム管理者 & 1 名（指導医） & & \\
\hline 研修委員会（下部委員会） & 設置 & 設置 & \\
\hline 研修委員会委員長 & 1 名（指導医） & 1 名（指導医） & \\
\hline 臨床研究センター, 倫理委員会 & 設置 & & \\
\hline 新指導医必要人数（上記役職） & 3 名以上 & 1 名以上 & \\
\hline 研修体制（13 領域） & 7 領域以上を研修できる & & \\
\hline 研修体制（70 疾患群） & 35 以上の疾患群を研修できる & & \\
\hline JMECC & 開催* & & \\
\hline 医療倫理講習会 & 開催 & 原則として開催 & \\
\hline 医療安全講習会 & 開催 & 原則として開催 & \\
\hline 地域参加型カンファレンス & 開催 & 参加 & 参加 \\
\hline $\mathrm{CPC}$ & 開催 & 参加 & \\
\hline （内科指導医講習会） & 開催 & 参加 & 参加 \\
\hline 学術活動 内科学会総会/地方会 & 演題 3 題以上 & 演題 1 題以上 & \\
\hline 施設実施調查 & 要対応 & & \\
\hline 年度毎募集上限 & \multicolumn{3}{|c|}{$\begin{array}{c}\text { 専門研修施設群の内科指導医数（合算）を募集上限とする. } \\
\text { (科領域 プログラム整備基準項目 } 27 \text { を参照) }\end{array}$} \\
\hline
\end{tabular}

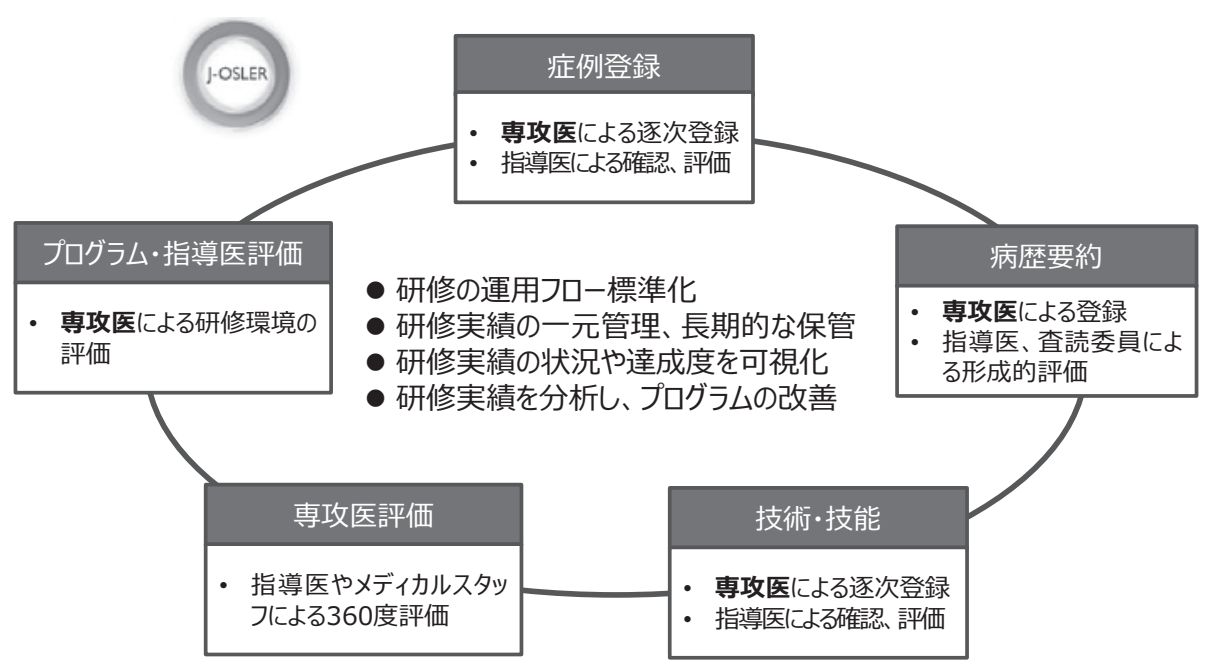

図 2 内科 Web 版研修手帳 (J-Osler)

J-OSLER (Japanese-Online system for Standardized Log of Evaluation and Registration)により, 研修プログラムの稼働状況も可視化され，研修プログラムの質の評価と改善に資することができ る．専攻医・指導医の指導過程や相互評価のログを残すことができる．本システムを用いて病歴 要約を提出し, 形成的評価も行われる。多職種評価（360 度評価）により専攻医の研修態度や研 修医によりプログラムも評価される。そして，これらの評価は専門医機構によるサイトビジット により検証される. 


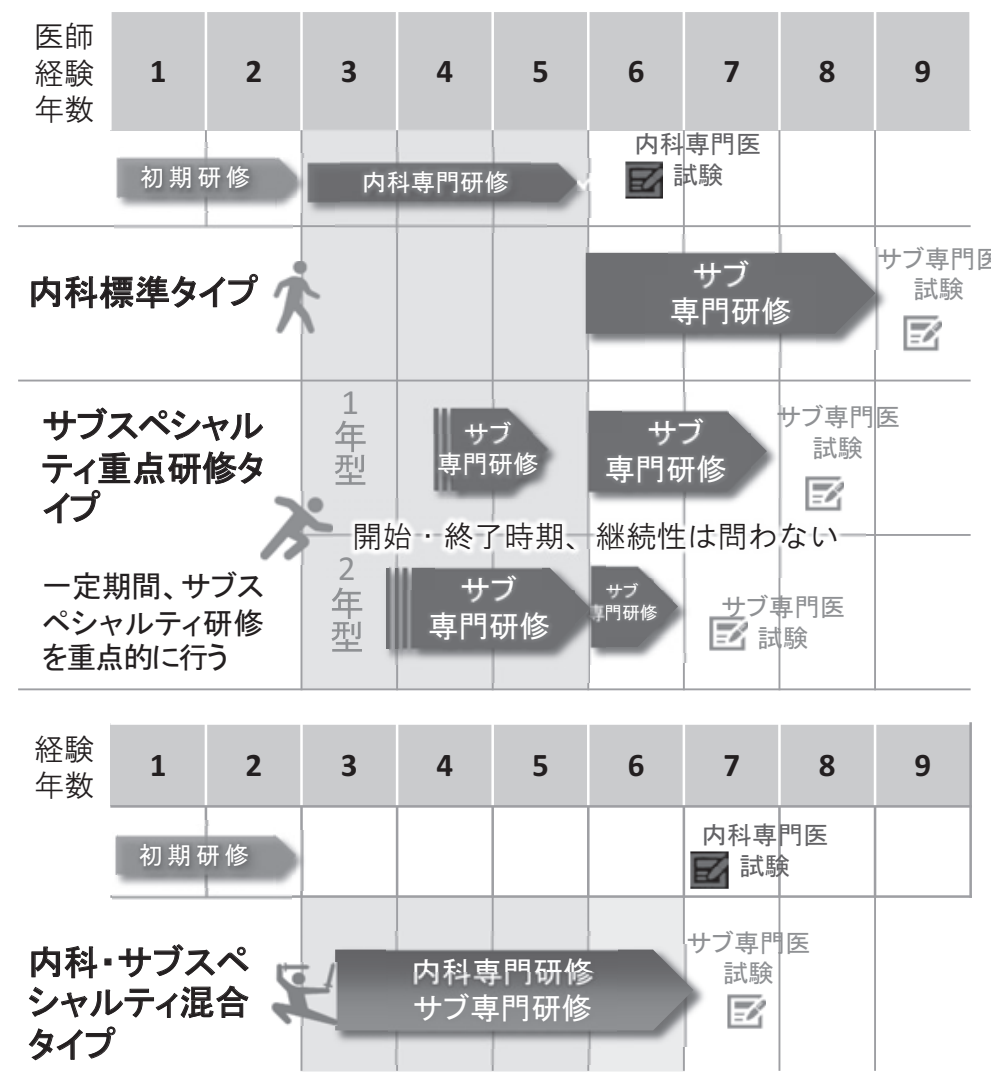

図 3 プログラムごとに多様な研修コース設定が可能 専攻医の希望, 地域の事情や特性に配慮した様々な研修コースをプログラムに設けることが可能 である。いずれのコースにおいても内科研修の修了要件は同じであるため, 研修の自由度はあり つつも「研修の質」は保たれる. 3 年間同じ施設に勤務する必要がある場合は最下段の内科・サ ブ混合型を選択する。なお，この混合型はサブ重点研修夕イプの連動研修 2 年型と研修期間が同 じであるが, 卒後 6 年目に内科専門医試験は受験できないが, 7 年目にサブ専門医と同年に受験 できる。

で（図 3: 標準タイプ）, 特に女性医師から subspecialty 領域専門医取得が遅れてしまうと強く懸念され た.しかし，プログラムの修了要件（主病名・主担当 医として 160 症例以上, 内科領域 56 疾患群以上）に は, 初期研修中の適切な症例経験も 80 例まで含める ことが可能であり, さらに外来症例を全体の 1 割含め ることが認められていることから，もし 2 年間の連動 研修（図 $3:$ サブスペ重点 2 年タイプあるいは混合夕 イプ）を行えば従来と全く同じ卒後 6 年でサブ専門医 の取得要件を達成することができる（図 4)。これま でのように個人任せではないため, 多くのプログラム が最短で専門医を取得させるであろうと予想されるこ とから, サブ領域も含め全体として専門医取得は従来
よりも早まると考えられる。

\section{プログラムの現状}

2018 年から新専門医研修が開始され，内科は 542 プログラム, 専攻医数は 2,671 名（全領域：8,394 名） となった。 この数字によって内科領域は大きく減少し たと解釈する向きもあるが，過去の卒後 $4 \sim 6$ 年目の 認定医試験受験者数は平均 2,570 名であり（図 5), ま た内科学会への研修医の新規入会者数は年間約 2,500～2,600 名であることから，今回の登録者数はそ れほど増減していないと考えるのが妥当であろう。総 合診療領域（184名）が追加されたものの, 内科全体 


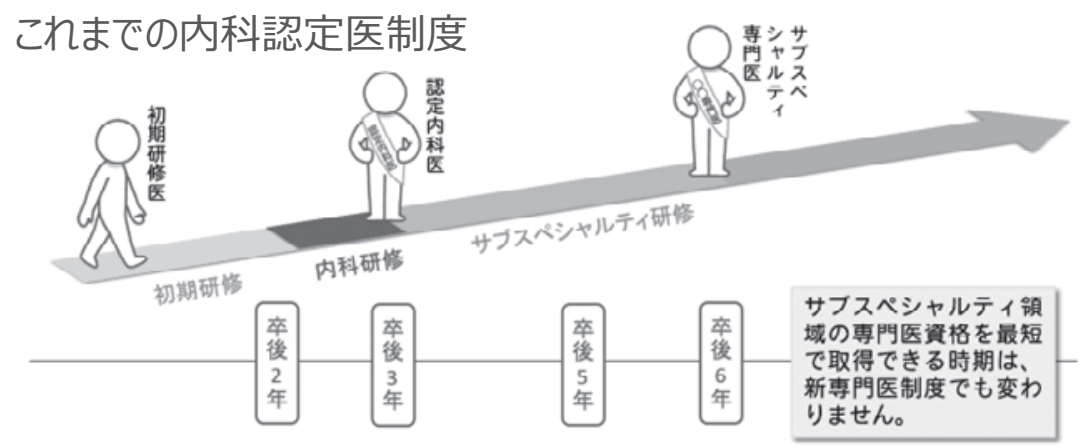

新しし内科専門医制度

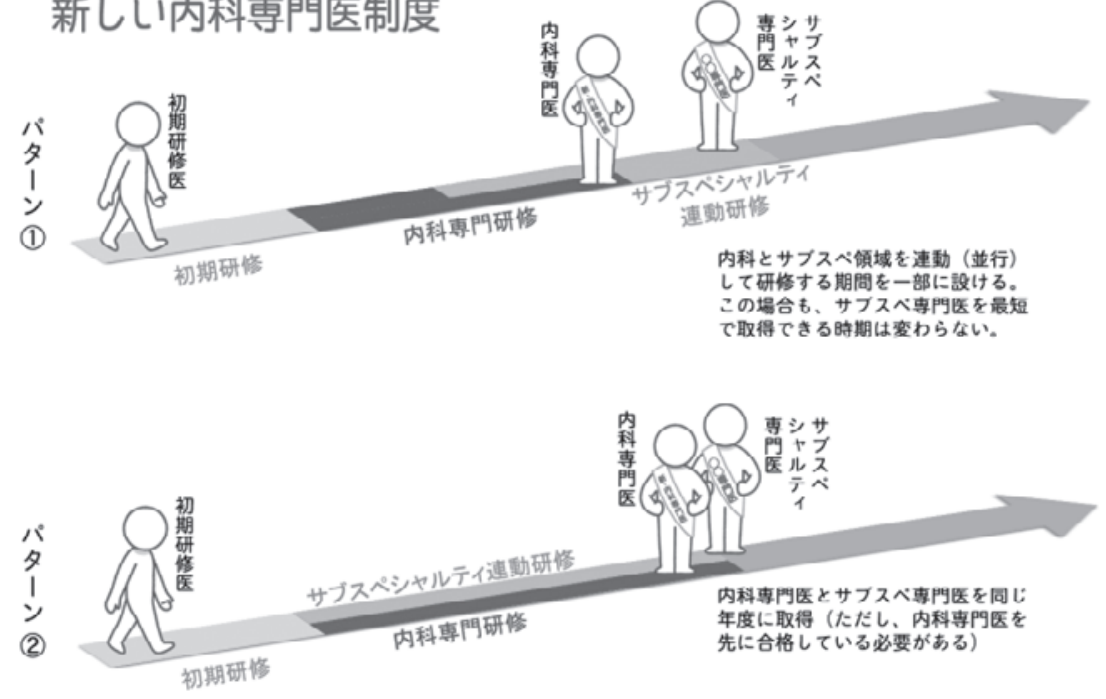

図 4 サブスペシャルティ専門医取得までの期間の新旧比較

サブ領域専門医取得を急ぐ人のために, 連動研修や初期研修期間中の症例登録を可能としている. パターン (1) は図 3 の連動研修 2 年型, パターン (2) は混合型である。これらの研修コースでは, 新 制度においても旧制度と同様に，最短では 7 年目でサブ領域の専門医の取得が可能となっている (http://www.naika.or.jp/nintei/shinseido2018-2/shinseido_faq より).

としてはこれまでに近い研修医数であると考えられ る.もちろん, 各地域では増減があるが, そもそも比 較対象の過去の数字が正確とは言えず，新制度開始に より, 正確な専攻医数が把握可能となったことが最も 大きな収穫の一つといえる。

2019 年に向かっては 21 プログラムが新規に申請さ れ，合計 563 プログラムとなる予定である．過去実績 を超えないとする 5 都府県のシーリングは継続される が，新たな医療法の成立に伴って，現時点で専門医機 構は特に東京都は本年実績（536 名）の 5\% 削減を要 請している。ただし，過去実績からの削減であり，東 京都の内科領域のシーリング值は 541 名となってい る. 東京都の今後の医療ニーズは著しく増大すること
が予想され，また他県への医師派遣機能も有するが, 専攻医は全体の $20 \%$ 存在しており，人口が $10 \%$ であ ることを考慮されているのかもしれない.

\section{内科のサブスペシャルティとしての総 合内科專門医}

当初, 総合内科専門医は指導医と位置づけ, 廃止す る方向で議論されていた。 しかしながら, 若い頃にサ ブスペシャルティ専門医として診療していた医師も, 年齢を積むと次第に総合内科に移行することが多く, また，新制度が当初の generalityを目標としたもの から，連動研修などサブ専門医に傾いた制度になって 


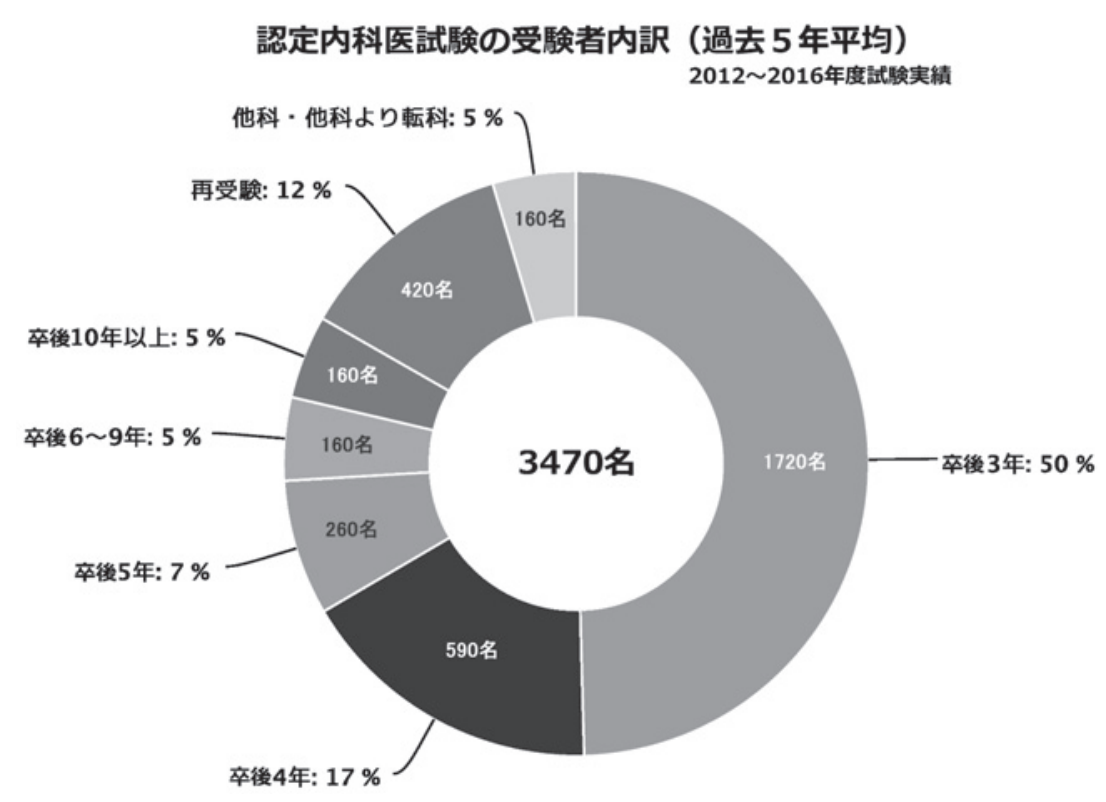

図 5 認定内科医の受験者の卒年の内訳

2016 年までの 5 年間の平均では 3,500 名ほどの受験者数であったが, そのうち満 3 年が 1,720 名 と半数であり, 満 3 年 + 満 4 年で 2,310 名, 満 5 年までで 2,570 名であった. 10 年未満では 2,730 であり, 本年の内科専攻医数とおおむね一致する (本文参照).

きたとの批判もあった。そこで, 種々の議論の結果, 内科領域にジェネラリティを主眼としたサブ専門医を 持つべきであるという結論となり, 総合内科専門医を 内科のサブスペシャルティとして再定義することが内 科理事会で承認された。

同様の generality を主とした専門医に総合診療専 門医があるが，これとの差別化はある程度は明瞭であ る. 総合内科専門医は内科領域のプロフェッショナル であるが，総合診療専門医は内科にとどまらず広く地 域の問題を扱う点で大きく異なる. しかし, 救急患者 を診る医師がすべて救急専門医ではないのと同様に， 地域を診る医師は総合診療専門医に限られるわけでは ない．地域の診療所でのプライマリーケアにおいても 内科の占める割合は各診療科の中で最も大きいと考元 られ，それぞれの特性を生かして地域医療に貢献して いくのが望ましい.

\section{サブスペシャルティ領域について}

老年医学領域を含め各サブ領域学会は連動研修を行
う実態から自主的に整備基準を作成した，共通して 3 年以上の研修期間とし，その期間に妥当と思われる症 例数の設定, 経時的に研修を評価するシステムを設け るなどの申し合わせを行い，2017 年 10 月に日本専門 医機構から整備基準が 13 領域すべてで暫定的に承認 されている，ただし，サブ領域の整備指針を機構が今 後作成する可能性もあり, 変更が必要となるかもしれ ない状況にある。

現在内科学会では, 臨床腫瘍および消化器内視鏡専 門医，そして上述の総合内科専門医が内科のサブ領域 として新たに認定され，機構へ整備基準も提出されよ うとしている。 そのほかにも多数の専門医が内科系に あるが，機構内でサブ領域の認定に関するワーキング が開始され，統一的な基準が作成されつつある.なお, 内科領域のサブ専門医については, 総合診療専門医か ら直接取得することは制度上不適切であり, 総合診療 専門医にはダブルボードとして内科専門医を取得する 道を担保し，将来サブの専門医となることもできるよ うにすべきであろう。 


\section{おわりに}

内科の新専門医制度は 2018 年から開始され，今の ところ順調に経過している。しかし，新制度に問題が ないわけではなく，特に，わが国における医学研究能 力の低下が指摘されており，専門医制度との両立を 図っていくべきであろう。ただ，新制度は我々医師の ために改変されているものではなく，国民の目線に沿 うものであり，本来，国や国民の利益となるべきもの である。この点では研修の実態こそ重要であり，より よい専門医を輩出できる専門医制度とするのは，これ まで通り個々の指導医であり, 指導施設であるのは変
わりがない.

著者の COI（Conflict of Interest）開示：本論文発表内 容に関連して特に申告なし

\section{文献}

1）渡辺 毅：新しい内科系専門医制度の概観 歴史的経 緯を踏まえて。纳会誌 2015; 104: 1152 .

2）横山彰仁：新・内科専門医像. 日内会誌 2015； 104: 1452 .

3）横山彰仁：新 - 内科専門医制度について。 日内会誌 2015; 104: 2539 